である. $\mathrm{N}_{2}$ の外に $\mathrm{CO}_{2}$ を泠却ダスとして用い成功し た。 $\mathrm{CO}_{2}$ は $\mathrm{N}_{2} よ り$ 加り小さい中性子吸收をも方， 椧却特性をややまさっている。現在さらに高温に耐え るウラニウム棒染準䚚中で，これ方出来上ると出力は 現在の2倍になる予定である。【西川 榢康】

\subsection{9 .445}

[323]クーラント虬よびモデレータとして水を周い

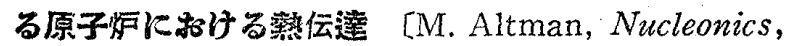
1956, Vol. 14, No. 2, p. 66 73, 図 6] ずへてて の動力用原子归においては，熱的，原子师的扔よび穖械 的の三つの買なった観点からの設計が部合されねばな らない。本諭文は水により泠却抢よび減速される原子

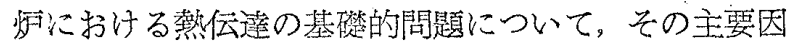
子を設計者にはあくさせるために書かれたもので，熱 伝達原子丣技術に関してその問題点を明らかにしたも のである。まず定常状熊において高い熱伀達係数をう る三つの方法一喬流速と表面澌騰一のあることを のべ，その得失を論じている，高流速の採朋は高いポ ンプ動力笠必要とする功，表面淜滕を起させると，低 い燃料表面温琶，生力および流量で同一の熱量を除去

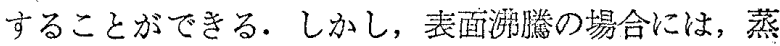
気の接合による伝熟阻害あるいはバーンアウトという 危険な現象加付属する。さらに過源状態，たとえばポ ンプ破損あるいは制御要素が作動しなくなった場合に

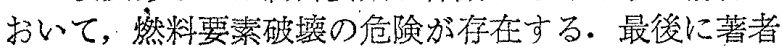

は結論をのベず，次のような間を発して本文を結んで いる，(i) 付属系内のある領域で沸騰が起れば，ぼの ような状態功発生するか。（ii）クーラントによる侵食 によって，モ゙うゆう絬果が生ずるか。（iii）冷却体の 温度吕䭂和に近い場合に起る流量および過冷度におけ るバーンアウト僨荷に運転の安全性が関係することが 本当ならぼ，定常状態において飽和近くで匴鞋するこ とは安全ではないのであろう方（iv）付属系内拉 び付属系閒における流れの安定に対する基準は何であ. るか。

[酉川! 謙康]

\section{$621.039: 629.12$}

†[324〕船用原子力機関〔Engg., 1955-12-23, Vol. 180 , No. 4691, p. 859 861, 図 4] $16000 \mathrm{SH}$ 以 上の油そう船用原動機として原子力は在来原動機と競

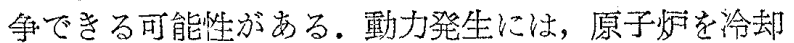
した Helium を密閉サイクルダスタービンに省いて動 力を発生する方式汃船用としては最方有望である。そ の理由は，ボイラや中間的熱交換器が不要なこと, $\mathrm{He}$ は放射性を字びず，また高純度で得易いから，原子即

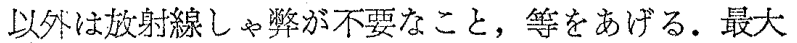
の難点はタービン嵮のパッキングであろう。原子炸内 の然料から万 Xenon ガスがもれ出してきても, Xe は椧却すれば液化するから容易に除去しうる。ガスタ ービンは二軸式がよいだうう。【石谷 清幹]

\title{
太陽熱利用飞関する文献
}

昨年 10 月 31 日より 11 月 5 日まで米国において 開催された第 1 回国際太陽熱利用会㨾に発表された総 合報告および研究報告が今回単行本として出版され一 般に売出されることになった。慧名，洒格等は次のご とくである;一

1. 総合報告(フェーニクス市の Symposiumにおけ る報告). Proceedings of the World Symposium on Applied Solar Energy. (A 4版, 300 ページ布製) 定価 5 ドル

2. 研究報告 (ツーソン市の Conference に括ける 報告). Transaction of the Conference on Solar Energy-The Scientic Basis. これは A. Thermal Processes; B. Photochemical Processes; C. Electrical Processes; D. Solar Radiation Measurement の 4 篇に分れ，各篇を別冊とし
3.また 1955 年に Stanford 研究所が世界の主な 27個国について太陽熱利用の現状を調查して 1 冊の書 物にまとめた次の書物も売出されている。

Applied Solar Energy Research

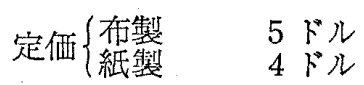

4. 太陽熱利用協会 (The Association For Applied Solar Energy 略号 AFASE) への入会と月刊 誌発行について

AFASE は太陽熱和用に関する国際的機関として月 刊誌 The Journal of Solar Energy を発行し,これ を会冒に配ることになった。会歵は個人会員のProfessional Member が一程安く年 10 ドルである。

なお以上の珰籍の発行所は

The Association for Applied Solar Energy, 204 Heard Building, Phoenix, Arizona, U.S.A.

(餍大工学部 - 谷下 市松)

\section{雜誌複写について}

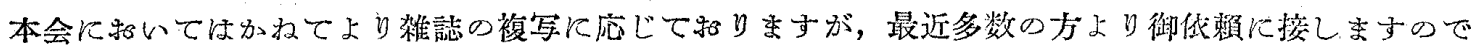
複写御希望の方は下記により本会古て招申达少下さい。

料 金 四 切 $(200 \mathrm{~mm} \times 300 \mathrm{~mm}) 1$ 校 $100 \mathrm{~m}$ 八 切 $(150 \mathrm{~mm} \times 200 \mathrm{~mm}) 1$ 枚 50 由

フィルム $(25 \mathrm{~mm} \times 35 \mathrm{~mm}) 1$ 枚 20 青ネ汸 $(200 \mathrm{~mm} \times 300 \mathrm{~mm}) 1$ 枚 100 円

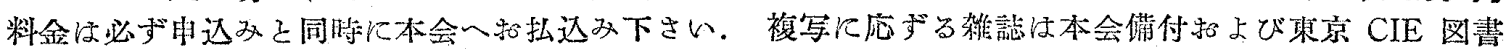

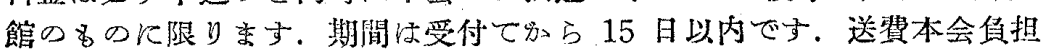

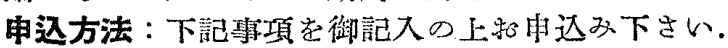
(1) 䊮誌名
(2) 著者名
（3）題名 （4）年次
(5) 巻号数
(6) ペーシ
（7）大きさ（四切，） 